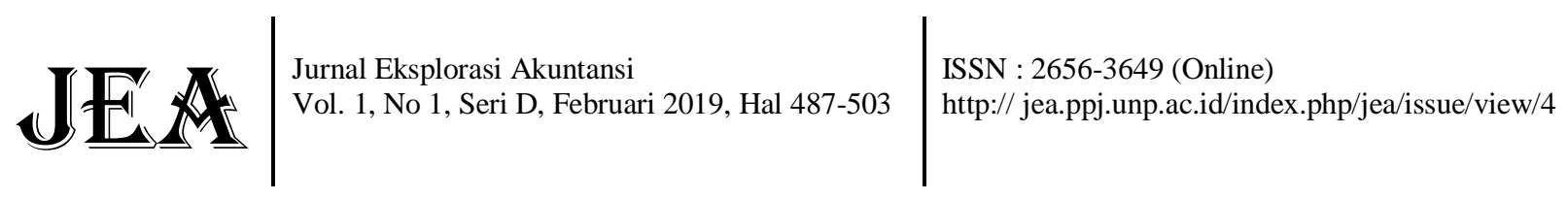

\title{
PENGARUH KEPEMILIKAN INSTITUSIONAL TERHADAP NILAI PERUSAHAAN DIMODERASI OLEH CORPORATE SOCIAL RESPONSIBILITY
} (Studi Empiris pada Perusahaan Property dan Real Estate yang Terdaftar di BEI Tahun 2015-2017)

\author{
Shabran Jamil ${ }^{1}$, Erinos NR ${ }^{2}$, Mayar Afriyenti ${ }^{3}$ \\ 1)Alumni Jurusan Akuntansi Fakultas Ekonomi Universitas Negeri Padang \\ ${ }^{2,3)}$ Jurusan Akuntansi Fakultas Ekonomi Universitas Negeri Padang \\ *Korespondensi: shabranjamil@yahoo.com
}

\begin{abstract}
This study aims to find empirical evidence regarding the relationship between institutional ownership and company value which is moderated by corporate social responsibility $(C S R)$. The population in this study were 48 property and real estate companies listed on the Stock Exchange in 2015-2017, with the number of samples used was 35 companies. The data used is secondary data in the form of annual reports obtained from the IDX website (www.idx.co.id). The testing in this study was conducted with moderated regression analysis (MRA). The results show that institutional ownership has no effect on corporate value and Corporate Social Responsibility (CSR) has not been able to moderate the moderation between institutional ownership and firm value.
\end{abstract}

Keywords: Institutional Ownership, CSR, Corporate Value

How to cite (APA $6^{\text {th }}$ style)

Jamil, S., Erinos, N. R. \& Afriyenti, M. (2019). Pengaruh Kepemilikan Institusional terhadap Nilai Perusahaan Dimoderasi oleh Corporate Social Responsibility (Studi Empiris pada Perusahaan Property dan Real Estate yang Terdaftar di BEI pada Tahun 2015-2017). Jurnal Eksplorasi Akuntansi, 1(1) Seri D, 487-503.

\section{PENDAHULUAN}

Berdirinya sebuah perusahaan memiliki tujuan yang jelas, baik dalam jangka pendek maupun jangka panjang. Menurut Isti'adah (2015) tujuan utama perusahaan adalah untuk memperoleh laba, sedangkan tujuan jangka panjangnya memberikan kemakmuran bagi pemilik perusahaan atau pemegang saham dan memaksimalkan nilai perusahaan yang tercermin pada harga saham perusahaan. Menurut Ika dan Shidiq (2013) nilai perusahaan adalah nilai yang mencerminkan berapa harga yang bersedia dibayar oleh investor untuk suatu perusahaan. Memaksimalkan nilai perusahaan sangat penting artinya bagi perusahaan, karena memaksimalkan nilai perusahaan 
berarti juga memaksimalkan kemakmuran pemegang saham yang merupakan tujuan utama perusahaan.

Nilai perusahaan dapat diukur dari beberapa aspek salah satunya harga pasar saham perusahaan, karena harga pasar saham perusahaan dinilai dapat mencerminkan penilaian investor terhadap keseluruhan ekuitas yang dimiliki (Wahyudi dan Pawestri dalam Paradnyana dan Putra,2018). Nilai perusahaan sangat penting karena dapat mempengaruhi persepsi investor, salah satunya adalah investor yang berasal dari institusional. Anggraini (2011) mengungkapkan salah satu struktur kepemilikan yang cukup besar dalam sebuah perusahaan adalah kepemilikan institusional. Kepemilikan institusional merupakan kepemilikan saham perusahaan yang mayoritas dimiliki oleh institusi atau lembaga (perusahaan asuransi, bank, perusahaan investasi, asset management dan kepemilikan institusi lain).

Penelitian yang dilakukan Herawati (2008) dan Margaritis dan Psillaki (2010) dan Haryono (2017) yang menemukan pengaruh positif dan signifikan struktur kepemilikan institusional terhadap kinerja perusahaan. Hasil ini menjelaskan semakin tinggi tingkat kepemilikan institusional suatu perusahaan maka akan semakin tinggi nilai perusahaan. Bangun (2012),dalam Nilasari (2013) mengungkapkan kepemilikan institusional memiliki arti penting dalam memonitor kinerja manajemen sebagai pencegahan terhadap kecurangan yang dilakukan oleh manajemen, karena keberadaan kepemilikan institusional akan mendorong peningkatan pengawasan yang lebih optimal. Susilo (2017) menyatakan semakin besar persentase saham yang dimiliki oleh pihak institusional akan menyebabkan pengawasan yang dilakukan menjadi lebih efektif karena dapat mengendalikan perilaku oportunistik manajer, dengan demikian kepemilikan institusional akan mendorong manajer selalu menunjukkan kinerja yang baik dihadapan para pemegang saham yang nantinya akan membawa pengaruh terhadap nilai perusahaan.

Jensen dan Meckling (1976) dalam isti'adah (2015) mengungkapkan bahwa kepemilikan institusional juga merupakan salah satu alat yang dapat digunakan untuk mengurangi konflik keagenan. Konflik keagenan akan menimbulkan biaya agensi, biaya tersebut merupakan biaya yang digunakan untuk memonitor perilaku agen dan biaya yang dikeluarkan untuk menjamin bahwa agen tidak bertindak merugikan principal. Tingkat kepemilikan institusional yang tinggi menyebabkan semakin kuatnya tingkat pengendalian yang dilakukan oleh pihak eksternal terhadap perusahaan, sehingga biaya agensi semakin berkurang dan nilai perusahaan akan semakin meningkat.

Penelitian yang dilakukan Herawati (2008), Margaritis dan Psillaki (2010) dan Haryono (2017) berbanding terbalik dengan penelitian yang dilakukan dengan Isti'adah (2015) yang menyimpulkan kepemilikan institusional tidak berpengaruh terhadap nilai perusahaan, selanjutnya penelitian yang dilakukan Susilo (2017) menyatakan kepemilikan institusional berpengaruh positif dan tidak signifikan terhadap nilai perusahaan. Hasil yang tidak konsiten pada penelitianpenelitian terdahulu menandakan adanya variabel lain yang mempengaruhi hubungan diantara keduanya. Murray (1990) dalam Paradnyana dan Putra (2018) menjelaskan bahwa agar dapat merekonsiliasi hasil yang saling bertentangan diperlukan pendekatan kontijensi untuk mengidentifikasi variabel lain yang bertindak sebagai pemoderasi ataupun pemediasi dalam model riset, maka penulis menambahkan Corporate Social Responsibility (CSR) sebagai variabel moderasi.

Pengungkapan CSR yang dilakukan suatu perusahaan dapat meningkatkan nilai perusahaan tersebut, sebab Teori Stakeholder menjelaskan bahwa perusahaan diwajibkan untuk mengungkapkan informasi kegiatan CSR yang dilakukan perusahaan sebagai suatu bentuk rasa 
tanggung jawab perusahaan terhadap stakeholder yang terkena dampak langsung maupun tidak langsung dari keberadaan perusahaan (Ghozali dan Chariri, 2007).

Menurut Nilasari (2013) tanggung jawab sosial perusahaan atau Corporate Social Responsibility (CSR) merupakan suatu gagasan yang menjadikan perusahaan tidak lagi dihadapkan pada tanggung jawab yang berpijak pada single bottom line, yaitu nilai perusahaan (corporate value) yang direfleksikan dalam kondisi keuangan (financial) saja. Tanggung jawab perusahaan harus berpijak pada triple bottom lines yaitu kondisi keuangan, masalah sosial dan lingkungan. Suatu organisasi perusahaan memiliki suatu tanggung jawab yang besar terhadap pemegang saham, karyawan, konsumen, komunitas, dan lingkungan dalam aspek operasional perusahaan (Kusumadilaga,2010).

Permasalahan tentang Corporate Social Responsibility (CSR) di Indonesia diatur dalam Pasal 74 ayat 1 Undang-Undang No.40 Tahun 2007 tentang Perseroan Terbatas bahwa perseroan yang menjalankan kegiatan usahanya di bidang berkaitan dengan sumber daya alam wajib melaksanakan tanggung jawab sosial dan lingkungan, dan Undang-Undang Republik Indonesia Nomor 32 Tahun 2009 tentang Perlindungan dan Pengelolaan Lingkungan Hidup. Peraturan mengenai pengungkapan CSR diatur oleh Keputusan Ketua Badan Pengawas Modal dan Lembaga Keuangan (Bapepam-LK), kemudian pada tanggal 31 Desember 2012 sesuai dengan UndangUndang Republik Indonesia Nomor 21 tahun 2011 tugas pengawasan industri keuangan non-bank dan pasar modal secara resmi beralih dari Bapepam-LK ke Otoritas Jasa Keuangan (OJK). OJK menerbitkan Peraturan Otoritas Jasa Keuangan Nomor 51 Tahun 2017 mengenai CSR perusahaan publik wajib menerapkan keuangan berkelanjutan dalam kegiatan perusahaan publik (Pradnyana dan Putra,2018).

Penelitian yang dilakukan oleh para peneliti diatas masih menunjukkan hasil yang tidak konsisten. Hasil yang beragam ini menunjukkan bahwa perbedaan karakter perusahaan sampel dan variable yang diukur akan sangat menentukan apakah kepemilikan institusional dan CSR memberikan perbedaan makna atau tidak pada nilai perusahaan.

\section{REVIU LITERATUR DAN PENGEMBANGAN HIPOTESIS}

\section{Teori Agency}

Teori keagenan (agency theory) menjelaskan bahwa hubungan agensi muncul ketika satu orang atau lebih (principal) memperkerjakan orang lain (agent) untuk memberikan suatu jasa dan kemudian mendelegasikan wewenang pengambilan keputusan kepada agent tersebut (Jensen dan Meckling, 1976). Agency theory menjelaskan bagaimana pihak - pihak yang terlibat dalam perusahaan (manajer, pemilik perusahaan dan kreditor) akan berperilaku, karena pada dasarnya mereka memiliki kepentingan yang berbeda. Manajer mempunyai kewajiban untuk memaksimumkan kesejahteraan para pemegang saham, namun disisi lain manajer juga mempunyai kepentingan untuk memaksimumkan kesejahteraan mereka.

Masalah keagenan dapat terjadi karena akibat dari adanya masalah bahaya moral dan seleksi yang salah. Masalah bahaya moral dapat terjadi karena prinsipal yang hanya memiliki akses yang kecil untuk memperoleh informasi kinerja perusahaan dan tidak dapat mengawasi seluruh keputusan dan tindakan yang diambil agen maka sering kali agen bebas mengejar kepentingannya sendiri. Akibatnya, agen merancang strategi yang memberikan manfaat terbesar baginya dengan cara menempatkan kesejahteraan organisasi sebagai prioritas sekunder (Pearce dan Robinson,2008: 48). Konflik yang terjadi akan memperbesar biaya keagenan (agency cost), untuk itu konflik dapat diminimalisir dengan cara para pemilik perusahaan mengadakan pengawasan 
terhadap kinerja para manajer salah satunya dengan kepemilikan saham oleh institusional (Haruman, 2008).

\section{Teori Stakeholder}

Perusahaan bukanlah entitas yang hanya beroperasi untuk kepentingannya sendiri serta hanya berorientasi pada keuntungan semata, namun harus memberikan manfaat bagi stakeholder-nya yang dalam hal ini terdiri atas pemegang saham, kreditor, konsumen, pemasok, pemerintah, masyarakat, analis dan pihak lain (Ghozali dan Chariri 2007).

Teori stakeholder merupakan teori yang menjelaskan bagaimana manajemen perusahaan memenuhi atau mengelola harapan para stakeholder. Teori stakeholder menekankan mengenai akuntabilitas organisasi jauh melebihi kinerja keuangan atau ekonomi sederhana. Teori ini menyatakan bahwa organisasi akan memilih secara sukarela mengungkapkan informasi tentang kinerja lingkungan, sosial dan intelektual mereka, melebihi dan diatas permintaan wajibnya, untuk memenuhi ekspektasi sesungguhnya atau yang diakui oleh stakeholders (Pradnyana dan Putra,2018).

\section{Nilai Perusahaan}

Nilai perusahaan dapat terlihat dari kemauan investor membeli saham perusahaan yang beredar berdasarkan harga yang ditentukan oleh investor. Harga yang dibayar investor tinggi, maka dapat dikatakan nilai perusahaan tinggi begitu juga sebaliknya. Nilai perusahaan yang tinggi menjadi keinginan para pemilik perusahaan, sebab dengan nilai yang tinggi menunjukkan kemakmuran pemegang saham juga tinggi. Investor juga cenderung lebih tertarik menanamkan sahamnya pada perusahaan yang memiliki kinerja baik dalam meningkatkan nilai perusahaan.

$$
\text { Tobin's } \mathrm{Q}=\frac{\text { Market value of equity }+ \text { Total Debt }}{\text { Total Asset }}
$$

\section{Kepemilikan Institusional}

Kepemilikan institusional akan mendorong manajer selalu menunjukkan kinerja yang baik dihadapan para pemegang saham yang nantinya akan membawa pengaruh terhadap nilai perusahaan. Tingkat kepemilikan institusional yang tinggi akan menimbulkan usaha pengawasan yang lebih besar oleh pihak investor institusional sehingga dapat menghalangi perilaku opportunistic manajer. Menurut Shleifer and Vishny dalam Permanasari (2010) bahwa institutional shareholders, dengan kepemilikan saham yang besar memiliki insentif untuk memantau pengambilan keputusan perusahaan.

Wibowo (2016) menyatakan kepemilkan institusional memiliki kelebihan antara lain (1) memiliki profesionalisme dalam menganalisis informasi sehingga dapat menguji keandalan informasi, (2) memiliki motivasi yang kuat untuk melaksanakan pengawasan yang lebih ketat terhadap aktivitas yang terjadi didalam perusahaan. Kepemilikan Institusional diukur melalui proporsi kepemilikan saham yang dimiliki institusional pada akhir tahun yang diukur dalam persentase saham yang dimiliki oleh investor institusional dalam suatu perusahaan.

$$
K I=\frac{\text { jumlah saham yang dimiliki institusi }}{\text { jumlah saham yang beredar }}
$$




\section{Corporate Social Responsibility}

Menurut The World Business Council for Sustainable Development (WBCSD), corporate social responsibility atau tanggungjawab sosial perusahaan didefinisikan sebagai komitmen bisnis untuk memberikan kontribusi bagi pembangunan ekonomi berkelanjutan, melalui kerja sama dengan para karyawan serta perwakilan mereka, keluarga mereka, komunitas setempat maupun masyarakat umum untuk meningkatkan kualitas kehidupan dengan cara yang bermanfaat baik bagi bisnis sendiri maupun untuk pembangunan.

Permasalahan tentang Corporate Social Responsibility (CSR) di Indonesia diatur dalam Pasal 74 ayat 1 Undang-Undang No.40 Tahun 2007 tentang Perseroan Terbatas bahwa perseroan yang menjalankan kegiatan usahanya di bidang dan/atau berkaitan dengan sumber daya alam wajib melaksanakan tanggungjawab sosial dan lingkungan. Pengungkapan CSR yang dilakukan suatu perusahaan dapat meningkatkan nilai perusahaan tersebut, sebab perusahan yang mengungkapkan informasi kegiatan CSR yang dilakukan perusahaan sebagai suatu bentuk rasa tanggungjawab perusahaan terhadap stakeholder yang terkena dampak langsung maupun tidak langsung dari keberadaan perusahaan (Ghozali dan Chariri,2007 dalam Pradnyana dan Putra 2018).

\section{Pengaruh Kepemilikan Institusional terhadap Nilai Perusahaan}

Adanya monitoring yang efektif dari kepemilikan institusional terhadap manajer dapat mendorong kinerja manajemen, sehingga manajer akan cenderung untuk berusaha meningkatkan kesejahteraan pemegang saham dan nilai perusahaan. Tingkat kepemilikan institusional yang tinggi akan menimbulkan usaha pengawasan yang lebih besar oleh pihak investor institusional sehingga dapat menghalangi perilaku opportunistic manajer. Jensen dan Meckling (1976:12) dalam isti'adah (2015) mengungkapkan bahwa kepemilikan institusional juga merupakan salah satu alat yang dapat digunakan untuk mengurangi agency conflict. Semakin tinggi tingkat kepemilikan institusional maka semakin kuat tingkat pengendalian yang dilakukan oleh pihak eksternal terhadap perusahaan, sehingga biaya agensi semakin berkurang dan nilai perusahaan akan semakin meningkat.

Menurut Shleifer and Vishny (dalam Permanasari,2010) bahwa institutional shareholders dengan kepemilikan saham yang besar memiliki insentif untuk memantau pengambilan keputusan perusahaan. Penelitian Wening (dalam Permanasari,2010) semakin besar kepemilikan oleh institusi maka semakin besar pula kekuatan suara dan dorongan untuk mengoptimalkan nilai perusahaan. Dengan demikian, penelitian ini memprediksi bahwa kepemilikan institusional berpengaruh positif terhadap nilai perusahaan, sehingga hipotesis pertama yang diajukan adalah: H1: Kepemilikan institusional berpengaruh positif terhadap nilai perusahaan.

\section{Corporate Social Responsibility sebagai Variable Moderasi Antara Kepemilikan Institusional dan Nilai Perusahaan}

Corporate Social Responsibility merupakan strategi perusahaan untuk memuaskan keinginan para stakeholder (Putri dan Raharja,2013). Pengungkapan CSR yang baik dilakukan suatu perusahaan dapat meningkatkan nilai perusahaan tersebut, sebab perusahan yang mengungkapkan informasi kegiatan CSR yang dilakukan perusahaan sebagai suatu bentuk rasa tanggungjawab perusahaan terhadap stakeholder yang terkena dampak langsung maupun tidak langsung dari keberadaan perusahaan (Ghozali dan Chariri,2007 dalam Pradnyana dan Putra 2018).

Penelitian Ali et al. (2007), menyatakan bahwa kepemilikan perusahaan oleh institusi akan mendorong pengawasan yang lebih efektif, karena institusi merupakan profesional yang memiliki kemampuan dalam mengevaluasi kinerja perusahaan. Hal itu berarti dengan adanya kepemilikan 
institusional segala tindakan manajer akan diawasi oleh kepemilikan Institusional dan dapat mendorong kualitas dan kuantitas pengungkapan CSR. Sesuai dengan signalling theory yang menyatakan bahwa pengungkapan CSR merupakan sinyal positif bagi investor dalam melakukan investasi, karena penciptaan nilai pemangku kepentingan dapat dipandang sama dengan menciptakan nilai pemegang saham (Warsono, 2009), tetapi penelitian Triyono \& Setyadi (2015) menyatakan bahwa CSR tidak terpengaruh secara signifikan terhadap nilai perusahaan.

Pengungkapan Corporate Social Responsibility yang semakin baik dilakukan perusahaan, maka stakeholder akan memberikan dukungan penuh kepada perusahaan atas segala aktivitasnya yang bertujuan untuk menaikkan kinerja dan mencapai laba serta pada akhirnya menaikkan nilai perusahaan. Fonbrun dan Shanley (1990) dikutip Putri dan Raharja (2013) yang menyatakan bahwa dalam teori stakeholders, strategi Corporate Social Responsibility akan mengarahkan pada kinerja yang lebih baik melalui perlindungan dan peningkatkan reputasi dan nilai perusahaan. Berdasarkan landasan teori dan hasil tersebut, maka hipotesis dalam penelitian ini adalah

H2: Corporate Social Responsibility memperkuat hubungan antara kepemilikan institusional terhadap nilai perusahaan.

Berdasarkan uraian di atas maka dapat digambarkan kerangka konseptual sebagai berikut:

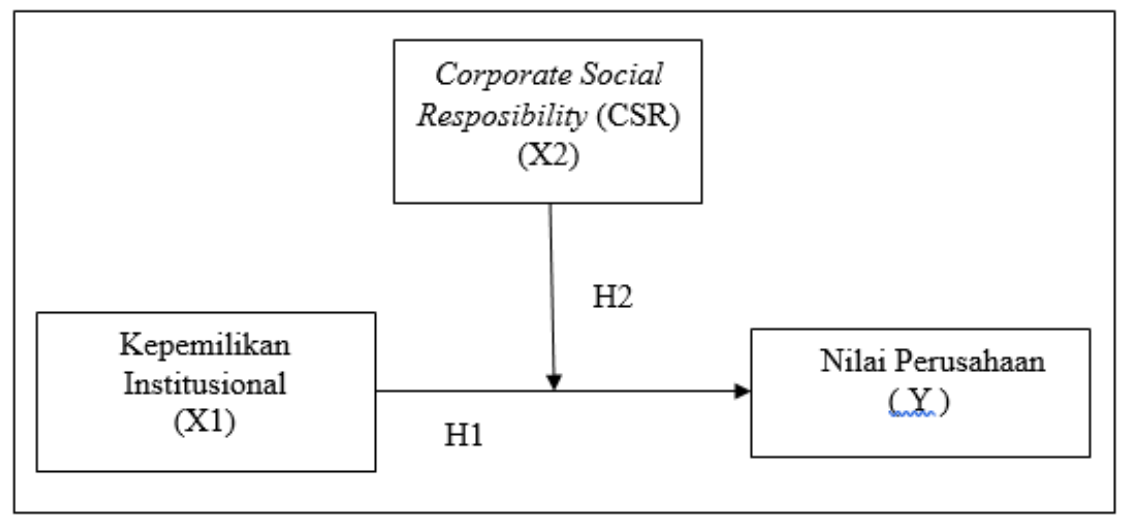

Gambar 1. Kerangka Konseptual

\section{METODE PENELITIAN}

\section{Jenis Penelitian}

Jenis penelitian ini termasuk penelitian asosiatif (hubungan), yaitu penelitian yang bertujuan untuk mengetahui hubungan dua variabel atau lebih. Berdasar tingkat penjelasan dari kedudukan variabelnya maka penelitian ini bersifat asosiatif kausal, yaitu penelitian yang mencari pengaruh (hubungan) sebab akibat (kausal) karena bertujuan untuk mengetahui pengaruh variabel bebas (independen) terhadap variabel terikat (dependen)(Sugiono,2012).

\section{Populasi dan Sampel}

Populasi adalah wilayah generalisasi yang terdiri atas: obyek/ subyek yang mempunyai kualitas dan karakteristik tertentu yang ditetapkan oleh peneliti untuk dipelajari dan kemudian ditarik kesimpulannya (Sugiyono, 2012). Populasi dalam penelitian ini adalah perusahaan property dan real estate yang terdaftar di Bursa Efek Indonesia (BEI) pada tahun 2015 sampai 2017 yang berjumlah 48 perusahaan. 
Teknik pengambilan sampel pada penelitian ini menggunakan teknik purposive sampling yaitu teknik pengambilan sampel berdasarkan kriteria-kriteria tertentu. Perusahaan yang akan diteliti adalah perusahaan property dan real estate. Kriteria sampel dalam penelitian ini adalah:

1) Perusahaan property dan real estate yang terdaftar di BEI yang menerbitkan laporan keuangan yang telah diaudit untuk periode yang berakhir 31 Desember selama periode penelitian yaitu tahun 2015-2017.

2) Perusahaan tidak memiliki ekuitas negatif selama periode penelitian yaitu tahun 2015-2017.

3) Perusahaan tidak mengalami delisting dan tidak ganti sektor selama periode penelitian yaitu tahun 2015 sampai 2017.

4) Memiliki data yang lengkap terkait dengan variabel-variabel yang digunakan dalam penelitian.

\section{Tabel 1}

Kriteria Pemilihan Sampel

\begin{tabular}{lc}
\hline Keterangan & $\begin{array}{l}\text { Jumlah } \\
\text { Perusahaan }\end{array}$ \\
\hline $\begin{array}{l}\text { Perusahaan property dan } \\
\text { real estate yang terdaftar di } \\
\text { Bursa Efek Indonesia tahun }\end{array}$ & 48 \\
$\begin{array}{l}\text { 2015-2017 } \\
\text { Tidak memenuhi kriteria } \\
\text { pertama } \\
\text { Tidak memenuhi kriteria } \\
\text { kedua } \\
\text { Tidak memenuhi kriteria } \\
\text { ketiga }\end{array}$ & $(7)$ \\
$\begin{array}{l}\text { Tidak memenuhi kriteria } \\
\text { keempat }\end{array}$ & 0 \\
Total sampel & 0 \\
\hline
\end{tabular}

\section{Jenis, Sumber dan Teknik Pengumpulan Data}

Jenis data yang digunakan dalam penelitian ini adalah data dokumenter yang berupa laporan keuangan perusahaan property dan real estate yang terdaftar di Bursa Efek Indonesia (BEI) pada tahun 2015-2017. Sumber data dalam penelitian ini adalah sumber data sekunder yaitu data yang diperoleh secara tidak langsung dan data tersebut sudah diolah oleh pihak lain. Data diperoleh dari akses internet melalui website IDX www.idx.co.id. Teknik pengumpulan data dalam penelitian ini adalah teknik dokumentasi dengan mengumpulkan dan melihat annual report perusahaan property dan real estate pada tahun 2015-2017 yang dipublikasikan melalui website IDX www.idx.co.id.

\section{Analisis Data}

\section{Uji Asumsi Klasik}

\section{a) Uji Normalitas}

Uji normalitas dimaksudkan untuk menguji apakah nilai residual yang telah terstandarisasi pada model regresi berdistribusi normal atau tidak (Suliyanto, 2011). Uji normalitas pada penelitian ini dengan menggunakan uji Kolmogorov-Smirnov. Jika nilai probabilitas lebih besar dari nilai alpha (Sig. $>\alpha$ ), maka nilai residual yang telah terstandarisasi pada model regresi berdistribusi normal. 


\section{b) Uji Heteroskedastisitas}

Heteroskedastisitas berarti ada varian variabel pada model regresi yang tidak sama (konstan) (Suliyanto, 2011). Model regresi yang diharapkan adalah homoskedastisitas yaitu varian variabel pada model regresi memiliki nilai yang sama (konstan). Uji heteroskedastisitas pada penelitian ini dengan menggunakan metode scatterplot. Cara untuk mendeteksi ada atau tidaknya heteroskedastisitas yaitu dengan melihat grafik plot antara nilai prediksi variabel terikat (dependen) yaitu ZPRED dengan residualnya SRESID. Deteksi ada tidaknya pola tertentu pada grafik scatterplot antara SRESID dan ZPRED dimana sumbu Y adalah Y yang telah diprediksi, dan sumbu $\mathrm{X}$ adalah residual (Y prediksi - Y sesungguhnya) yang telah di - studentized.

\section{c) Uji Autokorelasi}

Uji autokorelasi bertujuan untuk mengetahui apakah ada korelasi antara anggota serangkaian data observasi yang diuraikan menurut waktu (time-series) atau ruang (cross section) (Suliyanto, 2011). Uji autokorelasi pada penelitian ini dengan menggunakan metode Durbin Watson (Durbin Watson Test). Model regresi yang baik adalah model regresi yang tidak terdapat autokorelasi.

\section{Uji Hipotesis}

Data yang telah dikumpulkan, dianalisis dengan menggunakan alat analisis statistik yakni Multiple Regression Analysis (MRA)

$$
\mathrm{Y}=\alpha+\beta_{1} X_{1}+\beta_{2} X_{2}+\beta_{3} X_{1} X_{2}+e
$$

Keterangan :

$\mathrm{Y}=$ Nilai Perusahaan

$\alpha \quad=$ Konstanta

$\beta_{1}-\beta_{2}=$ Koefisien Regresi

$\mathrm{X}_{1} \quad=$ Kepemilikan Institusional

$\mathrm{X}_{2} \quad=$ Corporate Social Responsibility

$\mathrm{X}_{1} \mathrm{X}_{2}=$ Interaksi antara Kepemilikan Institusional dengan CSR

$\mathrm{E}=$ Error Term, yaitu tingkat kesalahan penduga dalam penelitian

Pengujian hipotesis akan dilakukan dengan program SPSS16, untuk mempermudah perhitungan statistik dengan melihat nilai berikut:

\section{a) Uji F}

Uji statistik F dilakukan untuk menguji kelayakan model (goodness of fit) yang digunakan dalam analisis regresi. Uji F yaitu uji bersama-sama variabel independen terhadap variabel dependen. Tingkat kepercayaan untuk pengujian hipotesis adalah $95 \%$ atau $(\alpha)=5 \%$.

\section{b) Uji t}

Uji statistik t pada dasarnya menghitung seberapa jauh pengaruh satu variabel independen dalam menerangkan variasi variabel dependen. Uji t yaitu uji pengaruh masing-masing variabel independen terhadap variabel dependen. Tingkat kepercayaan untuk pengujian hipotesis adalah $95 \%$ atau $(\alpha)=5 \%$. 


\section{c) Koefisien Determinasi}

Koefisien determinasi (R2) digunakan untuk mengukur seberapa jauh kemampuan sebuah model dalam menerangkan variabel dependen atau melihat besar peran variabel independen terhadap variabel dependen.

\section{HASIL DAN PEMBAHASAN}

Perusahaan property dan real estate merupakan salah satu sektor industri yang terdaftar di Bursa Efek Indonesia (BEI). Perusahaan yang listing di BEI dalam sektor ini beberapa tahun terakhir semakin banyak, ini menunjukkan perkembagan dalam dunia property dan real estate. Tahun 2015-2017 populasi sektor ini sebanyak 48 perusahaan dan yang menjadi sampel dalam penelitian ini sebanyak 35 perusahaan.

\section{a. Uji Asumsi Klasik}

Sebelum data diolah dengan regresi berganda maka dilakukan uij asumsi klasik untuk memperoleh keyakinan bahwa data yang diperoleh beserta variabel penelitian layak untuk diolah lebih lanjut. Uji asumsi klasik dalam penelitian ini terdiri dari:

\section{1) Uji Normalitas}

Uji normalitas digunakan untuk menguji apakah distribusi data mengikuti atau mendekati distribusi normal. Data yang baik adalah data yang pola distribusinya normal. Uji normalitas dapat dilakukan dengan metode Kolmogorav-Smirnov test. Hasil pengolahan SPSS versi 16 didapat bahwa hasil uji normalitas menunjukkan level signifikasi lebih besar dari $\alpha(\alpha=0,05)$ yaitu $0,227>0,05$ sehingga data terdistribusi secara normal seperti tabel dibawah ini:

Tabel 2

Uji Kolmogorov-Smirnov

\begin{tabular}{ll}
\hline & $\begin{array}{l}\text { Unstandardiz } \\
\text { ed Residual }\end{array}$ \\
\hline $\mathrm{N}$ & 97 \\
Kolmogorov-Smirnov Z & 1.043 \\
Asymp. Sig. (2-tailed) & .227 \\
\hline Sumber : Data olahan 2019 &
\end{tabular}

\section{2) Uji Heterokedastisitas}

Pada hasil pengolahan data didapatkan grafik regresi scatterplot sebagai berikut, 


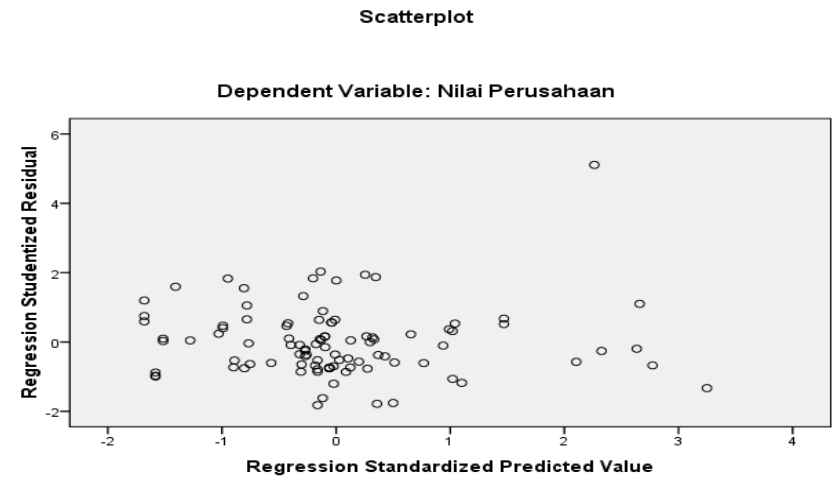

Sumber: Data olahan 2019

\section{Gambar 2. Hasil Uji Heterokedastisitas}

Gambar di atas menunnjukkan tidak terdapat pola tertentu pada grafik scatterplot antara SRESID dan ZPRED dimana sumbu $\mathrm{Y}$ adalah residual (Y prediksi-Y sesungguhnya) yang telah distandardized. Jadi tidak ada pola yang jelas, serta titik menyebar di atas dan di bawah angka 0 pada sumbu $\mathrm{Y}$, maka dapat disimpulkan tidak terjadi heterokedastisitas dan layak untuk diteliti.

\section{3) Uji Autokorelasi}

\begin{tabular}{|c|c|}
\hline \multicolumn{2}{|c|}{$\begin{array}{c}\text { Tabel 3 } \\
\text { Uji Durbin- Watson }\end{array}$} \\
\hline Model & Durbin-Watson \\
\hline 1 & 1.941 \\
\hline
\end{tabular}

Hasil uji autokorelasi menunjukkan bahwa nilai Durbin-Watson adalah 1,941. Nilai DU pada tingkat signifikan 5\% adalah 1,7209 yang berarti nilai DW sebesar 1,941 berada diantara Du $=1,702$ dan $4-\mathrm{Du}=2,288$ sehingga regresi tidak terdapat gejala autokorelasi.

\section{b. Uji Hipotesis}

1) Moderated Regression Analysis

Penelitian ini melakukan uji interaksi untuk menguji variabel moderating yang berupa religiusitas dengan dengan menggunakan Moderated Regression Anlyisis (MRA). MRA merupakan aplikasi khusus regresi linier berganda, dimana dalam persamaan regresinya mengandung unsur interaksi perkalian dua atau lebih variabel independen (Ghozali,2011). Perhitungan statistik dalam analisis regresi linear berganda yang digunakan dalam penelitian ini adalah dengan menggunakan bantuan program komputer SPSS 16. Ringkasan hasil pengolahan data dengan menggunakan program SPSS 16 tersebut adalah sebagai berikut: 


\section{Tabel 4 Coefficients}

\begin{tabular}{|c|c|c|c|c|c|c|}
\hline \multirow[b]{2}{*}{ Model } & & \multicolumn{2}{|c|}{ Unstandardized Coefficients } & \multirow{2}{*}{$\begin{array}{c}\text { Standardized } \\
\text { Coefficients }\end{array}$} & \multirow[b]{2}{*}{$\mathrm{T}$} & \multirow[b]{2}{*}{ Sig. } \\
\hline & & $\mathrm{B}$ & Std. Error & & & \\
\hline \multirow[t]{4}{*}{1} & (Constant) & 1.314 & .389 & & 3.380 & .001 \\
\hline & Kepemilikan Institusi & -.789 & .552 & -.346 & -1.430 & .156 \\
\hline & CSR & -1.549 & 1.312 & -.440 & -1.181 & .241 \\
\hline & Moderasi & 3.448 & 1.879 & .758 & 1.835 & .070 \\
\hline
\end{tabular}

Sumber : Data olahan 2019

Berdasarkan tabel 4.11 dapat dianalisis model persamaan sebagai berikut:

$$
\mathrm{Y}=1,314-0,789 \mathbf{X}_{1}-1,549 \mathbf{X}_{2}+3.348 \mathbf{X}_{1} * \mathbf{X}_{2}+\boldsymbol{e}
$$

Keterangan :

$\mathrm{Y}=$ Nilai perusahaan

$\mathbf{X}_{\mathbf{1}} \quad=$ Kepemilikan Institusional

$\mathbf{X}_{2} \quad=$ CSR

$\mathrm{X} 1 * \mathbf{X} 2=$ Moderasi

Berdasarkan persamaan regresi diatas dapat dijelaskan sebagai berikut:

\section{a) Konstanta $(\alpha)$}

Hasil uji analisis regresi berganda terlihat bahwa konstanta sebesar 0,891 menunjukkan bahwa tanpa adanya pengaruh dari variabel bebas yaitu Kepemilikan institusional dan CSR sebagai pemoderasi maka nilai perusahaan akan bernilai 0,891 .

\section{b) Koefisien regresi ( $\beta$ ) Kepemilikan Institusional}

Koefisien Kepemilikan institusional sebesar -0,210 hal ini menunjukkan jika varibel kepemilikan institusional meningkat satu satuan maka variabel nilai perusahaan akan menurun sebesar 0,210 dengan asumsi variabel lain bernilai nol.

\section{c) Koefisien regresi ( $\beta$ ) CSR}

Nilai koefisien CSR sebesar -1,549 hal ini menunjukkan jika variabel CSR meningkat satu-satuan maka nilai perusahaan akan menurun sebesar 1,549 dengan asumsi variabel lain bernilai nol.

\section{d) Koefisien regresi $(\boldsymbol{\beta}) \mathbf{X}_{1} * \mathbf{X}_{2}$}

Nilai koefisien $\mathbf{X}_{\mathbf{1}} * \mathbf{X}_{\mathbf{3}}$ sebesar 3.488, hal ini berarti setiap peningkatan CSR satu satuan maka akan menigkatkan pengaruh variabel kepemilikan institusional terhadap nilai perusahaan sebesar 1,310 dengan asumsi variabel lain nol.

\section{Uji kelayakan Model}

\section{a. Koefisien Determinasi $\mathbf{R}^{2}$}

Koefisien Determinasi ini digunakan untuk mengetahui seberapa besar kemampuan variabel bebas dalam menerangkan variabel terikat. Nilai determinasi ditentukan dengan nilai Adjusted R Square. 


\section{Tabel 5}

Koefisien Determinasi

\begin{tabular}{lrrrr}
\hline Model & R & R Square & $\begin{array}{c}\text { Adjusted R } \\
\text { Square }\end{array}$ & $\begin{array}{l}\text { Std. Error of } \\
\text { the Estimate }\end{array}$ \\
\hline 1 & $.286^{\mathrm{a}}$ & .082 & .052 & .45813 \\
\hline Sumber : Data olahan & 2019 & & &
\end{tabular}

Pada tabel 4.12 diketahui nilai adjusted $\mathrm{R}$ square adalah 0,052 atau 5,2\% variabel nilai perusahaan dijelaskan oleh kepemilikan institusional, CSR dan interaksi antara kepemilikan institusional dan CSR, dan sisanya yaitu sebesar 94,8\% dijelaskan oleh variabel-variabel lain diluar persamaan.

\section{a. Uji F}

Berdasarkan hasil analisis data yang diperoleh menguji hipotesis ini, maka dilakukan uji $\mathrm{F}$ dengan membandingkan nilai $F_{\text {hitung }}$ dengan $F_{\text {tabel. }}$ Pada level signifikansi 0,05, besar $F_{\text {tabel }}$ untuk $\mathrm{n}=97$ adalah 3,093. Hasil pengolahan statistik analisis regresi menunjukkan nilai $\mathrm{F}=3,428$ dan signifikan pada level 0,037. Jadi $F_{\text {hitung }}>F_{\text {tabel }}$ yaitu 3,428 > 3,093 (sig. 0,037<0,05), Hal ini menunjukkan bahwa model regresi dapat digunakan untuk menguji pengaruh variabel independen terhadap variabel dependen. Hasil analisis data yang diperoleh sebagai berikut:

Tabel 6

\section{Hasil uji F}

\begin{tabular}{|c|c|c|c|c|c|c|}
\hline \multicolumn{2}{|c|}{ Model } & $\begin{array}{l}\text { Sum of } \\
\text { Squares }\end{array}$ & \multirow[t]{2}{*}{ Df } & Mean Square & \multirow{2}{*}{$\begin{array}{l}F \\
3.428\end{array}$} & \multirow{2}{*}{$\begin{array}{l}\text { Sig. } \\
\quad .037\end{array}$} \\
\hline 1 & Regression & 1.445 & & .722 & & \\
\hline & Residual & 19.812 & 94 & .211 & & \\
\hline & Total & 21.257 & 96 & & & \\
\hline
\end{tabular}

Sumber: Data olahan, 2019

\section{b. Uji Hipotesis (t-test)}

Uji t statistik (t-test) bertujuan untuk mengetahui hubungan yang signifikan dari masing-masing variabel bebas terhadap variabel terikatnya. Pengujian hipotesis secara parsial dilakukan dengan cara membandingkan nilai $t_{\text {hitung }}$ dengan nilai $t_{\text {tabel }}$. Nilai $t_{\text {tabel }}$ adalah $\alpha=0,05$ dengan derajat bebas (db) adalah 2,280, berdasarkan hasil analisis pada tabel maka dapat diketahui pengaruh variabel independen terhadapa variabel dependen sebagai berikut.

\section{1) Hipotesis 1}

Variabel kepemilikan institusional memiliki nilai $-0,827<2,280$ dan nilai sig $0,410>0,05$ dengan nilai koefisien $\beta$ dari variabel kepemilikan institusional bernilai negatif yaitu $-0,210$. Hal ini menunjukkan bahwa kepemilikan saham oleh institusi tidak berpengaruh terhadap nilai perusahaan, $\mathbf{H}_{1}$ ditolak.

\section{2) Hipotesis 2}

Variabel interaksi $\left(\mathrm{X}^{1 *} \mathrm{X}^{2}\right)$ memiliki nilai $1,835<2,280$ dan nilai sig $0,070>0,05$ dengan nilai koefisien $\beta$ dari variabel interaksi bernilai positif yaitu 1,310. hal ini menunjukkan bahwa CSR 
belum mampu memoderasi hubungan antara kepemilikan institusional dengan nilai perusahaan dengan demikian $\mathbf{H}_{2}$ ditolak.

\section{Pembahasan \\ Pengaruh Kepemilikan Institusional terhadap Nilai Perusahaan.}

Berdasarkan hasil uji hipotesis pertama, menunjukkan bahwa variabel kepemilikan institusional tidak berpengaruh terhadap nilai perusahaan. Artinya kepemilikan institutional belum mampu manjadi mekanisme pengawasan pada nilai perusahaan sehingga belum ada dampaknya. Adanya asimetri informasi antara investor dengan manajer menyebabkan investor belum tentu sepenuhnya memiliki informasi yang dimiliki oleh manajer (sebagai pengelola perusahaan) sehingga manajer sulit dikendalikan oleh investor institusional. Kepemilikan institusional tidak berpengaruh terhadap nilai perusahaan karena tidak dapat memonitor perusahan.

Kepemilikan Institusi merupakan kepemilikan saham mayoritas dibuktikan dengan ratarata diatas 60\% dari total saham beredar. Menurut Pound dalam Dewi dan Sanica (2017), investor institusional mayoritas memiliki kecendrungan untuk berkompromi atau berpihak kepada manajemen dan mengabaikan kepentingan pemegang saham minoritas. Anggapan bahwa manajemen sering mengambil tindakan atau kebijakan yang non-optimal dan cenderung mengarah pada kepentingan pribadi mengakibatkan strategi aliansi antara investor institusional dengan pihak manajemen ditanggapi negatif oleh pasar. Hal ini tentunya berdampak pada penurunan harga saham perusahaan dipasar modal sehingga dengan kepemilikan institusional belum mampu menjadi mekanisme yang dapat meningkatkan nilai perusahaan.

Hasil ini konsisten dengan penelitian Dewi dan Sanica (2017) yang menunjukkan bahwa kepemilikan institusional tidak berpengaruh pada penelitiannya, Begitu juga dengan penelitian yang dilakukan oleh Nuraina (2012) bahwa kepemilikan institutional tidak berpegaruh terhadap nilai perusahaan.

\section{Pengaruh Kepemilikan Institusional terhadap Nilai Perusahaan dengan CSR sebagai Pemoderasi}

Berdasarkan uji hipotesis kedua, menunjukkan nilai t sebesar 1,835 dan tingkat signifikan sebesar 0,070 lebih besar dari 0,05 sehingga hipotesis kedua $\left(\mathrm{H}_{2}\right)$ ditolak. Pengungkapan CSR yang dilakukan perusahaan pada laporan tahunan belum mampu memoderasi hubungan antara kepemilikan institusional tehadap nilai perusahaan. Hasil ini sejalan dengan Hartana (2017), Prastuti (2015), Suryonugroho (2016) yang memperoleh CSR tidak dapat memoderasi antara kepemilikan institusi terhadap nilai perusahaan dan penelitian.

Rendahnya kualitas pengungkapan CSR menjadi faktor yang menyebabkan praktik CSR tidak berpengaruh terhadap nilai perusahaan. Kesadaran perusahaan yang rendah dalam melakukan CSR mengakibatkan pengungkapanya hanya sebesar 25\%. Pasal 74 ayat 1 UndangUndang No.40 Tahun 2007 tentang Perseroan Terbatas menjelaskan perseroan yang menjalankan kegiatan usahanya di bidang berkaitan dengan sumber daya alam wajib melaksanakan tanggung jawab sosial dan lingkungan, hal ini menyebabkan perusahaan hanya menjalankan program tanggung jawab sosialnya hanya sekedar untuk menghindari sanksi terhadap perusahaan. Belum adanya standar jelas mengenai pengungkapan menimbulkan perbedaan interpretasi yang bisa menjadi kontraproduktif dalam upaya menciptakan pemahaman yang sama mengenai CSR (Purnawati,2017). Oleh sebab itu, variabel CSR kurang menunjukkan kontribusi dalam mempengaruhi hubungan antara kepemilikan institusional terhadap nilai perusahaan. Investor di Indonesia mungkin lebih cenderung untuk membeli saham untuk memperoleh capital gain 
(peningkatan harga saham) yang cenderung membeli dan menjual saham secara harian (daily trader), tanpa memperhatikan keberlangsungan perusahaan dalam jangka panjang.

\section{PENUTUP}

\section{Kesimpulan}

Penelitian ini bertujuan untuk melihat apakah kepemilikan institutional berpengaruh terhadap nilai perusahaan dengan CSR sebagai variabel moderasi studi empiris pada perusahaan property dan real estate tahun 2015-2017. Berdasarkan hasil penelitian dan pengujian hipotesis yang telah dilaksanakan, maka hasil penelitian dapat disimpulkan bahwa (1) kepemilikan institutional tidak berpengaruh terhadap nilai perusahaan, (2) CSR tidak mampu memoderasi hubungan antara kepemilikan institusional terhadap nilai perusahaan.

\section{Keterbatasan}

Meskipun peneliti telah berusaha merancang dan mengembangkan penelitian sedemikian rupa, namun masih terdapat beberapa keterbatasan dalam penelitian yaitu (1) nilai Adjusted $R^{2}$ relatif rendah yaitu hanya 5,2\% sehingga masih terdapat variabel-variabel lain yang berpengaruh terhadap nilai perusahaan diluar model regresi, (2) sampel untuk penelitian ini hanya dilakukan pada perusahaan property dan real estate, (3) masih sedikit perusahaan go publik yang membuat laporan berkelanjutan (sustainability report).

\section{Saran}

Berdasarkan kesimpulan dari hasil penelitian yang telah dijelaskan diatas dapat diberikan saran sebagai berikut:

1. Peneliti selanjutnya dapat menggunakan variabel independen lain yang berpengaruh terhadap nilai perusahaan seperti GCG, ukuran perusahaan dan lain sebagainya.

2. Peneliti selanjutnya dapat menggunakan variabel moderasi lain yang berpengaruh terhadap nilai perusahaan seperti profitabilitas, solvabilitas dan lain sebagainya.

3. Penelitian selanjutnya menggunakan perusahaan yang mengeluarkan laporan berkelanjutan (sustainable report) agar dapat melihat pengaruh CSR.

4. Dilakukan penelitian lebih lanjut dengan membandingkan dengan sektorlain, sehingga sampel penelitian lebih besar dan dapat digeneralisasi.

\section{DAFTAR PUSTAKA}

Adnantara, K. F. (2013). Pengaruh Struktur Kepemilikan Saham dan Corporate Social Responsibility pada Nilai Perusahaan. Jurnal Buletin Studi Ekonomi Universitas Udayana, 18 (2), 107-113.

Anggraini, R. R. (2006). Pengungkapan Informasi Sosial dan Faktor-Faktor yang Mempengaruhi Pengungkapan Informasi Sosial dalam Laporan Keuangan Tahunan (Studi Empiris pada Perusahaan-Perusahaan yang terdaftar Bursa Efek Jakarta). Simposium Nasional Akuntansi IX, Padang.

Anggraini, R. D. (2011). Pengaruh Kepemilikan Institusional dan Kepemilikan Asing terhadap Pengungkapan Pertanggung jawaban Sosial Perusahaan dalam Annual Report (Studi Empiris pada Perusahaan Non Keuangan yang Tercatat di BEI Tahun 2008-2009). Skripsi. Semarang: Universitas Diponegoro. 
Bangun, N., Octavia, J. dan Tarigan, K. B. (2012). Pengaruh Kepemilikan Manajerial, Kepemilikan Institusional dan Profitabilitas terhadap Pengungkapan Corporate Social Responsibility pada Perusahaan yang Terdaftar di Bursa Efek Indonesia. Jurnal Akuntansi, 12(2), 717-738.

Bathala, C. T, Moon, K. P. dan Rao, R. P. (1994). Managerial Ownership, Debt Policy, and The Impact of Institutional Holdings: An Agency Perspective. Journal Financial Management, 38-50.

Bursa Efek Indonesia. Laporan keuangan dan tahunan. http://www.idx.co.id/id-id beranda/perusahaantercatat/laporankeuangandantahunan.aspx.Diakses $\operatorname{tanggal} 23$ September 2018.

Dewi, S. (2017). Pengaruh Kepemilikan Institusional, Kepemilikan Manajerial, dan Pengungkapan Corporate Social Responsibility terhadap Nilai Perusahaan Pada Perusahaan Manufaktur yang Terdaftar di Bursa Efek Indonesia. Jurnal Ilmiah Akuntansi dan Bisnis, 2(1).

Fahrizal, D. (2015).Pengaruh Modal Intelektual terhadap Nilai Perusahaan (Studi Empiris pada Perusahaan Keuangan yang Terdaftar di BEI tahun 2010-2013. skripsi. Jurusan Akuntansi FakultasEkonomi. Universitas Negeri Padang.

Ghozali dan Chariri. (2007). Teori Akuntansi. Semarang: Badan Penerbit Undip.

Gray, et. al. (1995). Corporate Social and Environmental Reporting: A Review of Literature and a Longitudinal Study of UK Disclosure. Accounting, Audiitng, and Accountability Journal, $8(2), 47-76$.

Haruman, T. (2008). Pengaruh Struktur Kepemilikan terhadap Keputusan Keuangan dan Nilai Perusahaan (Perspektif Agency Theory). National Converence on Management Research .

Haryono, F dan Fatima. (2017). Pengaruh Struktur Modal dan Struktur Kepemilikan Terhadap Kinerja Perusahaan. (The Effect of Capital Structure and Ownership Structure on Firm Performance). Jurnal Akuntansi dan Keuangan Indonesia, 14(2), 119-141.

Herawati, V. (2008). Peran Praktek Corporate Governance sebagai Moderating Variable dari Pengaruh Earnings Management terhadap Nilai Perusahaan. Simposium Nasional Akuntansi XI.

https://www.globalreporting.org/Pages/default.aspx. Diakses 28 September 2018.

Indahningrum, H. (2009). Pengaruh Kepemilikan Manajerial, Kepemilikan institusional, Dividen, Pertumbuhan Perusahaan, Free Cash Flow dan Profitabilitas terhadap Kebijakan Hutang. Jurnal Bisnis dan Akuntansi, 11(3), 189-207.

Jusriani, I. F. dan Rahardjo, S. N. (2013). Analisis Pengaruh Profitabilitas, Kebijakan Dividen, Kebijakan Utang, Dan Kepemilikan Manajerial Terhadap Nilai Perusahaan (Studi Empiris Pada Perusahaan Manufaktur di BEI Periode 2009-2011). Jurnal Akuntansi Diponegoro. 2(2), 1-10.

Isti'adah, U. (2015). Faktor-Faktor yang Mempengaruhi Nilai Perusahaan pada Perusahaan Manufaktur. Jurnal Nominal, 4(2), 57-72.

Jensen, M. C. and Meckling, W.H. (1976). Theory Of The Firm: Manajerial Behavior, Agency Cost And Ownership Structure. Journal Of Financial Economics, 3, 305-360.

Kusumadilaga, R. (2010). Pengaruh Corporate Social Responsibility terhadap Nilai Perusahaan dengan Profitabilitas sebagai Variabel Moderating (Studi Empiris pada Perusahaan Manufaktur yang Terdaftar di Bursa Efek Indonesia). Skripsi. Fakultas Ekonomi Univeristas Diponogoro Semarang. 
Kallapur, S. and Trombley, M. A. (1999). The Association Between Investment Opportunity Set Proxies and Realized Growth. Journal of Bussines Finance And Accounting. 26 (3)(4), 505-519.

Latupono, S. S. (2015). Pengaruh Corporate Social Responsibility terhadap Nilai Perusahaan: Good Corporate Governance Variabel Moderating. Jurnal Ilmu dan Riset Akuntansi Sekolah Tinggi Ilmu Ekonomi Indonesia, 4 (8), 1-14.

Margaritis, D. dan Psillaki, M. (2010). Capital Structure, Equity Ownership and Firm Performance. Journal of Banking \& Finance, 34, 621-632.

Murray, D. (1990). The Performance Effect of Participative Budgeting an Interpretation of Intervening and Moderating Variables. Behavioral Reseach in Accounting, 2, 104-123.

Nilasari, E. (2013). Pengaruh Profitabilitas, Kepemilikan Institusional, Kepemilikan Asing dan Size Terhadap CSR Disclosure Perusahaan Tambang (mining Sector) yang Melakukan Listing di Bursa Efek Indonesia Tahun 2010-2012. Jurnal Universitas Dian Nuswantoro Semarang.

Pearce II, John A. dan Robinson, R. B. J. (2008). Manajemen Strategis 10.Jakarta: Salemba Empat.

Peraturan Otoritas Jasa Keuangan Nomor 51 Tahun 2017 tentang Penerapan Keuangan Berkelanjutan bagi Lembaga Jasa Keuangan, Emiten, dan Perusahaan Publik. 27 Juli 2017. Jakarta.

Permanasari, W. (2010). Pengaruh Kepemilikan Manajemen, Kepemilikan Institusional, dan Corporate Social Responsibility terhadap Nilai Perusahaan. Skripsi. Semarang: Universitas Diponegoro.

Pradnyana, P. (2018). Moderasi Corporate Social Responsibility Pada Pengaruh Profitabilitas Terhadap Nilai Perusahaan Pada Perusahaan Manufaktur. E-Jurnal Akuntansi Universitas Udayana, 24(1), 253-281.

Rahayu, D. (2018). Pengaruh Corporate Social Responsibility dan Kinerja pada Nilai Perusahaan dengan Kepemilikan Asing sebagai Variabel Moderasi . E-Jurnal Akuntansi Universitas Udayana. 24(1), 30-57.

Saham OK. Sub Sektor konstruksi BEI. https://www.sahamok.com/emiten/sektor-property realestate/. Diakses tanggal 23 September 2018.

Sayekti, Y. dan Wondabio, L. S. (2007). Pengaruh CSR Disclosure terhadap Earning Response Coefficient. Simposium Nasional Akuntansi X. Makassar, 26-28 Juli.

Sinarmayarani, A. (2016), Pengaruh kepemilikan institusional dan profitabilitas terhadap nilai perusahaan melalui kebijakan dividen sebagai variabel intervening pada perusahaan food and beverages di Bursa Efek Indonesia periode 2010-2014. Jurnal Ilmu dan Riset Manajemen, 5(5), 2461-0593.

Sugiyono. (2012). Metode Penelitian Pendidikan (Pendekatan Kualitatif, Kuantitaif, dan R\&D). Bandung: Alfabeta.

Sukamulja, S. (2004). Good Corporate Governance di sektor keuangan: Dampak GCG terhadap kinerja perusahaan. Benefit, 8(1), 125.

Suliyanto. (2011). Ekonometrika Terapan: Teori \& Aplikasi dengan SPSS. Yogyakarta: Andi Offset.

Susilo, D. A. (2017). Pengaruh Kepemilikan Institusional, Free Cash Flow, dan Investment Opportunity Set Terhadap Nilai Perusahaan dengan Kebijakan Hutang sebagai Variabel Intervening. Jurnal Akuntansi dan Bisnis Universitas Pandanaran Semarang. 
Thesarani, N. J. (2015). Pengaruh Ukururan Dewan Komisaris, Kepemilikan Manajerial, Kepemilikan Institusional dan Komite Audit Terhadap Struktur Modal Perusahaan (Studi Empiris pada Perusahaan Manufaktur yang Terdaftar di BEI tahun 2012-2015). Skripsi. Universitas Negeri Yogyakarta.

Undang-Undang Republik Indonesia Nomor 21 Tahun 2011 tentang Otoritas Jasa Keuangan. 22 November 2011. Jakarta.

Undang-Undang Republik Indonesia Nomor 32 Tahun 2009 Tentang Perlindungan dan Pengelolaan Lingkungan Hidup. 3 Oktober 2009. Jakarta.

Undang-Undang Republik Indonesia Nomor 40 Tahun 2007 tentang Perseroan Terbatas. 16 Agustus 2007. Jakarta.

Wahyudi, Untung. Pawestri, hartini prasetyaning. 2006. Implikasi Struktur Kepemilikan terhadap Nilai Perusahaan dengan Keputusan Keuangan sebagai Variabel Intervening. Simposium Nasional Akuntansi IX Padang, 23-26. 